\title{
Composition and cytotoxic and antioxidant activities of the oil of Piper aequale Vahl
}

\author{
Joyce Kelly R. da Silva ${ }^{1 *}$, Laine C. Pinto ${ }^{2}$, Rommel M. R. Burbano², Raquel C. Montenegro ${ }^{1,2}$, \\ Eloísa Helena A. Andrade ${ }^{3}$ and José Guilherme S. Maia ${ }^{3,4}$
}

\begin{abstract}
Background: Piper aequale Vahl is a small shrub that grows in the shadow of large trees in the Carajás National Forest, Municipality of Parauapebas, Para state, Brazil. The local people have used the plant against rheumatism and inflammation.

Methods: The essential oil of the aerial parts was extracted and analyzed by GC and GC-MS. The MTT colorimetric assay was used to measuring the cytotoxic activity of the oil against human cancer lines. The determination of antioxidant activity of the oil was conducted by DPPH radical scavenging assay.

Results: The main constituents were $\delta$-elemene (18.92 \%), $\beta$-pinene (15.56 \%), a-pinene (12.57\%), cubebol (7.20 \%), $\beta$-atlantol (5.87\%), and bicyclogermacrene (5.51\%), totalizing $65.63 \%$ of the oil. The oil displayed a strong in vitro cytotoxic activity against the human cancer cell lines HCT-116 (colon) and ACP03 (gastric) with $\mathrm{IC}_{50}$ values of $8.69 \mu \mathrm{g} / \mathrm{ml}$ and $1.54 \mu \mathrm{g} / \mathrm{ml}$, respectively. The oil has induced the apoptosis in a gastric cancer cells in all tested concentration $(0.75-3.0 \mathrm{\mu g} / \mathrm{ml})$, after $72 \mathrm{~h}$ of treatment, when compared to negative control $(p<0.001)$. Also, the oil showed a significant antioxidant activity $(280.9 \pm 22.2 \mathrm{mg}$ TE/ml), when analyzed as Trolox equivalent, and a weak acetylcholinesterase inhibition, with a detection limit of $100 \mathrm{ng}$, when compared to the physostigmine standard (1.0 ng).

Conclusion: The higher cell growth inhibition induced by the oil of $P$. aequale is probably due to its primary terpene compounds, which were previously reported in the proliferation inhibition, in stimulation of apoptosis and induction of cell cycle arrest in malignant cells.
\end{abstract}

Keywords: Essential oil composition, Terpene compounds, Cytotoxic and antioxidant activities, Apoptosis

\section{Background}

Piperaceae comprises five genera and about 1400 species with a pantropical distribution [1]. Piper genus is the greater in the family and mainly distributed in the tropical and subtropical region of the world. It has been extensively investigated as the source of natural products with potential antifungal, antitumoral, antioxidant, antiplasmodial, and trypanocidal properties [2]. Moreover, Piper species are used to treat diseases, including jaundice, rheumatism, and neuralgia in the folk medicine of Asia and Pacific region [3]. Piper aequale Vahl, with several synonyms (http://www.tropicos.org/Name/25001129), is a shrub up $2.0 \mathrm{~m}$ with distribution throughout Central

\footnotetext{
* Correspondence: joycekellys@ufpa.br

${ }^{1}$ Programa de Pós-Graduação em Biotecnologia, Universidade Federal do

Pará, 66075-900 Belém, PA, Brazil

Full list of author information is available at the end of the article
}

America and Northern of South America [3, 4]. In the Northeastern of Pará state, Brazil, the decoction of leaves is used in the treatment of rheumatism and inflammation.

Piper species have presented many classes of compounds, such as unsaturated amides, flavonoids, lignans, aristolactams, long and short chain esters, steroids, and alkaloids [5]. Moreover, the oils of Piper in the Brazilian Amazon have shown terpenoid and phenylpropanoid compounds as major constituents [6,7]. Few works with $P$. aequale were published. The chemical studies have reported the presence of benzofuranoid neolignans and the mono- and sesquiterpenes compounds in the aerial parts $[8,9]$; the insecticidal and larvicidal activity of the ethanolic extract [10]; as well the bactericidal activity of the ethanolic extract and essential oil [11]. 
The aim of this study was to identify the composition of the oil of Piper aequale and evaluate their cytotoxic, antioxidant and anticholinesterase properties.

\section{Methods}

\section{Plant material}

The aerial parts (leaves and thin stems) of Piper aequale were collected in the Carajás National Forest, Municipality of Parauapebas, Pará state, Brazil, February 2008. A voucher (MG 189272) was deposited in the herbarium of Emilio Goeldi Museum, Belém, Pará state, Brazil.

\section{Extraction of essential oil and composition analysis}

The plant material was air dried, pulverized and submitted to hydrodistillation using a Clevenger-type apparatus (100 g, $3 \mathrm{~h}$ ). The oil was dried over anhydrous sodium sulfate, and its percentage content was calculated based on the plant dry weight. The moisture content of the sample was calculated after phase separation in a Dean-Stark trap (5 g, $60 \mathrm{~min}$ ), using toluene.

The oil analysis was carried on a GC-MS Thermo Focus DSQ II, under the following conditions: DB- $5 \mathrm{~ms}$ (30 m $\times 0.25 \mathrm{~mm}, 0.25 \mathrm{~mm}$ film thickness) fused-silica capillary column; programmed temperature, $60-240{ }^{\circ} \mathrm{C}$ $\left(3{ }^{\circ} \mathrm{C} / \mathrm{min}\right)$; injector temperature, $250{ }^{\circ} \mathrm{C}$; carrier gas helium, adjusted to a linear velocity of $32 \mathrm{~cm} / \mathrm{s}$ (measured at $\left.100{ }^{\circ} \mathrm{C}\right)$; injection type, splitless $(2 \mu \mathrm{l}$ of a 1:1000 hexane solution); split flow was adjusted to yield a 20:1 ratio; septum sweep was a constant $10 \mathrm{ml} / \mathrm{min}$; EIMS, electron energy at $70 \mathrm{eV}$; temperature of the ion source and connection parts, $200{ }^{\circ} \mathrm{C}$. The quantitative data regarding the volatile constituents were obtained by peak area normalization using a FOCUS GC/FID operated under similar conditions for the GC-MS, except the carrier gas, which was nitrogen. The retention index was calculated for all volatiles constituents using an $n$-alkane (C8-C30, Sigma-Aldrich) homologous series [12].

\section{Antioxidant assay}

The antioxidant activity of the oil was evaluated by DPPH radical scavenging assay, using methodology adapted by us [13]. DPPH is a stable dark violet free radical with a maximum absorption at $517 \mathrm{~nm}$. Trolox, a hydrophilic carboxylic acid derivative of $\alpha$-tocopherol was employed to determine the radical scavenging activity, as a standard antioxidant. The radical-scavenging activity was expressed as milligrams of Trolox equivalent per milliliter of each sample (mgTE/ml).

\section{Acetylcholinesterase assay}

The acetylcholinesterase $(\mathrm{AChE})$ inhibition assay (by bioautography) is a rapid method and relatively free of disturbances by solvent [14]. The enzyme acetylcholinesterase $(500 \mathrm{U})$ was dissolved in tris-hydrochloric acid buffer
( $\mathrm{pH}$ 7.8) and stabilized by the addition of bovine serum albumin fraction V $(0.1 \%)$. TLC layers were spotted with the essentials oils in the range of 0.01 to $1000 \mathrm{ng} / \mathrm{spot}$. The alkaloid physostigmine was used as positive control. The plates were then sprayed with the enzyme solution $(3.33 \mathrm{U} / \mathrm{ml})$, thoroughly dried and incubated at $37{ }^{\circ} \mathrm{C}$ for 20 min (moist atmosphere). Enzyme activity was detected by spraying with a solution consisting of $0.25 \%$ of 1-naphtyl acetate in $\mathrm{EtOH}(5 \mathrm{ml})$ plus $0.25 \%$ aqueous solution of Fast Blue B salt $(20 \mathrm{ml})$. Potential acetylcholinesterase inhibitors appeared as clear zones on a purple colored background [15].

\section{Cytotoxicity against cancer cell lines}

The MTT colorimetric assay was usedfor measuring cell viability [16]. The oil $(0.4$ to $25.0 \mu \mathrm{g} / \mathrm{ml})$ was tested for cytotoxic activity against three cancer cell lines: HCT-116 (colon), SKMEL19 (melanoma) and ACP-03 (gastric). All cell lines were maintained in DMEM (Dulbecco's Modified Eagle Medium) supplemented with $10 \%$ fetal bovine serum, $2 \mathrm{mM}$ glutamine, $100 \mathrm{U} / \mathrm{ml}$ penicillin, $100 \mu \mathrm{g} / \mathrm{ml}$ streptomycin at $37{ }^{\circ} \mathrm{C}$ with $5 \% \mathrm{CO}_{2}$. The oil was dissolved to obtain a concentration of $10 \mathrm{mg} / \mathrm{ml}$ with DMSO. The final concentration of DMSO in the culture medium was kept constant, below $0.1 \%(\mathrm{v} / \mathrm{v})$. The oil was incubated with the cells for $72 \mathrm{~h}$. The negative control received the same amount of DMSO $(0.001 \%$ in the highest concentration). The cell viability was determined by reduction of the yellow dye 3-(4,5-dimethyl-2-thiazol)-2,5-diphenyl$2 \mathrm{H}$-tetrazolium bromide (MTT) to a blue formazan product. The $\mathrm{IC}_{50}$ 's values were calculated by nonlinear regression using GraphPad program (Intuitive Software for Science, San Diego, CA).

\section{Cell membrane disruption}

The potential of the cell membrane lyses was evaluated by releasing hemoglobin from erythrocytes in the medium. The test was performed in 96-well plates using a $2 \%$ mouse erythrocyte suspension in $0.85 \% \mathrm{NaCl}$ containing $10 \mathrm{mM} \mathrm{CaCl} 2$. The oils diluted as mentioned above were tested at $200 \mu \mathrm{g} / \mathrm{ml}$. After incubation at room temperature for $1 \mathrm{~h}$ and centrifugation, the supernatant was removed, and the liberated hemoglobin was measured spectrophotometrically at $540 \mathrm{~nm}$. DMSO was used as negative control and Triton X-100 (1\%) as the positive control [17].

\section{Evaluation of apoptosis and necrosis using differential fluorescent staining with ethidium bromide/acridine orange (EB/AO)}

Cells were seeded into 12 -well plates at a density of $1 \times 10^{4}$ cells/well, at $37^{\circ} \mathrm{C}$. After $24 \mathrm{~h}$ of incubation, cells were treated with the oil $(0.75 \mu \mathrm{g} / \mathrm{ml}, 1.5 \mu \mathrm{g} / \mathrm{ml}$ and $3.0 \mu \mathrm{g} / \mathrm{ml})$ for $72 \mathrm{~h}$. Doxorubicin $(1 \mu \mathrm{M})$ was used as a positive control. Cells were pelleted and resuspended in 
$20 \mu \mathrm{l}$ phosphate-buffered saline (PBS). Afterward, $1 \mu \mathrm{l}$ of an aqueous solution of EB/AO $(100 \mu \mathrm{g} / \mathrm{ml})$ was added and cells were observed under a fluorescence microscope (Olympus, Tokyo, Japan). Acridine orange intercalates into the DNA giving it a green appearance. Ethidium bromide also intercalates into DNA, making it appear orange, but it is only taken up by non-viable cells. Live cells with intact membranes have a uniform green color in their nuclei. Early apoptotic cells have chromatin condensation with bright green colored nuclei. Late apoptotic cells have bright orange areas of condensed chromatin in the nucleus that distinguish them from necrotic cells, which have a uniform orange color [18]. Three hundred cells were then classified as follows: live cells, apoptotic cells, and necrotic cells. The percentage of apoptotic cells and necrotic cells was then calculated. Experiments were performed in triplicate.

\section{Statistical analysis}

Samples were assayed in triplicate, and the results are shown as means \pm standard deviation. For antioxidant and cytotoxic screening, analysis of variance (ANOVA) was conducted by Tukey's test and for the apoptosis evaluation, the Bonferroni test was used. The values between means were considered statistically significant at $p<0.05$, using Graph Prism 5.0.

\section{Results and discussion \\ Composition of the oil}

The aerial parts (leaf and thin stems) of $P$. aequale provided an oil yield of $2.2 \%$,and GC and GC-MS analyzed its volatile constituents. The individual components were identified by comparison of both mass spectrum and GC retention data with those of authentic compounds existing in data system libraries $[19,20]$. Thirty-six components were identified and comprised to $92.4 \%$ of the total composition (Table 1). The oil was composed of sesquiterpenes hydrocarbons (42.5\%), followed by monoterpenes hydrocarbons $(29.1 \%)$ and oxygenated sesquiterpenes $(20.9 \%)$. The main constituents (above $5 \%$ ) were $\delta$ elemene (19.0\%), $\beta$-pinene (15.6), $\alpha$-pinene (12.6\%), cubebol (7.2\%), $\beta$-atlantol (5.9\%), and bicyclogermacrene (5.5\%).

The leaf oil of another specimen of $P$. aequale was reported to Monteverde, Costa Rica. It was composed by a high content of the monoterpene hydrocarbons $\alpha$ pinene $(39.3 \%)$, sabinene $(18.4 \%)$ and limonene $(6.7 \%)$ [9]. Therefore, the oil with occurrence in Costa Rica differs somewhat from the oil that is being presented in this work, whose principal constituent is $\delta$-elemene (19.0\%), a sesquiterpene hydrocarbon. However, as can be seen, the $\delta$-elemene is followed by $\alpha$-pinene and $\beta$ pinene, two monoterpene hydrocarbons. The isoforms
Table 1 Oil composition (\%) of Piper aequale

\begin{tabular}{|c|c|c|c|c|}
\hline No. & Constituents & $\mathrm{Rl}^{\mathrm{a}}$ & $\mathrm{Rl}^{\mathrm{b}}$ & Oil $\%$ \\
\hline 01 & a-Pinene & 937 & 932 & 12.6 \\
\hline 02 & $\beta$-Pinene & 980 & 974 & 15.6 \\
\hline 03 & Limonene & 1031 & 1024 & 1.0 \\
\hline 04 & $\delta$-Elemene & 1333 & 1335 & 19.0 \\
\hline 05 & a-Cubebene & 1345 & 1345 & 0.6 \\
\hline 06 & a-Ylangene & 1365 & 1373 & 0.6 \\
\hline 07 & a-Copaene & 1373 & 1374 & 0.9 \\
\hline 08 & $\beta$-Elemene & 1382 & 1389 & 2.6 \\
\hline 09 & a-Gurjunene & 1400 & 1409 & 0.1 \\
\hline 10 & $\beta$-Caryophyllene & 1415 & 1417 & 1.3 \\
\hline 11 & $\beta$-Ylangene & 1417 & 1419 & 0.4 \\
\hline 12 & $\gamma$-Elemene & 1426 & 1434 & 1.6 \\
\hline 13 & Aromadendrene & 1434 & 1439 & 0.1 \\
\hline 14 & cis-Muurola-3,5-diene & 1445 & 1451 & 0.4 \\
\hline 15 & a-Humulene & 1452 & 1452 & 0.7 \\
\hline 16 & allo-Aromadendrene & 1456 & 1458 & 0.3 \\
\hline 17 & Iswharane & 1464 & 1465 & 0.7 \\
\hline 18 & cis-Muurola-4(14),5-diene & 1465 & 1465 & 0.6 \\
\hline 19 & Germacrene D & 1477 & 1484 & 3.5 \\
\hline 20 & $\beta$-Selinene & 1485 & 1489 & 0.2 \\
\hline 21 & trans-Muurola-4(14),5-diene & 1487 & 1493 & 0.4 \\
\hline 22 & Bicyclogermacrene & 1492 & 1500 & 5.5 \\
\hline 23 & a-Muurolene & 1495 & 1500 & 0.7 \\
\hline 24 & Cubebol & 1511 & 1514 & 7.2 \\
\hline 25 & 8-Cadinene & 1515 & 1522 & 2.3 \\
\hline 26 & trans-Cadina-1,4-diene & 1529 & 1533 & 0.2 \\
\hline 27 & a-Cadinene & 1532 & 1537 & 0.1 \\
\hline 28 & Elemol & 1545 & 1548 & 1.4 \\
\hline 29 & Germacrene B & 1553 & 1559 & 0.1 \\
\hline 30 & Guaiol & 1592 & 1600 & 0.9 \\
\hline 31 & $\beta$-Atlantol & 1604 & 1608 & 5.9 \\
\hline 32 & epi-a-Muurolol & 1639 & 1640 & 2.1 \\
\hline 33 & a-Muurolol & 1642 & 1644 & 0.9 \\
\hline 34 & a-Cadinol & 1650 & 1652 & 2.0 \\
\hline 35 & Selin-11-en-4-a-ol & 1651 & 1658 & 0.1 \\
\hline 36 & Bulnesol & 1662 & 1670 & 0.4 \\
\hline \multicolumn{4}{|c|}{ Monoterpene hydrocarbons } & 29.2 \\
\hline \multicolumn{4}{|c|}{ Sesquiterpenes hydrocarbons } & 42.9 \\
\hline \multicolumn{4}{|c|}{ Oxygenated sesquiterpenes } & 20.9 \\
\hline \multicolumn{4}{|c|}{ Total } & 93.0 \\
\hline
\end{tabular}

Retention indices calculated for all volatile constituents using a homologous series of $n$-alkanes

${ }^{\mathrm{b}}$ Retention indices described in literature (Adams, 2007 [20])

The bold numbers represent the compounds with area percentage above $5 \%$ 
Table 2 Cytotoxic activity of the oil of $P$. aequale on cancer cell lines ${ }^{a}$

\begin{tabular}{lllll}
\hline Sample & & $I_{50}(\mu \mathrm{g} / \mathrm{ml})^{\mathrm{a}}$ & & Hemolysis \\
& HCT-116 (Colon) & SKMEL19 (Melanoma) & ACP-03 (Gastric) & $(\mu \mathrm{g} / \mathrm{ml})$ \\
\hline Oil & $8.69(7.20-10.50)$ & $>25$ & $1.54(1.34-1.77)$ & $>200$ \\
Doxorubicin & $0.10 \mu \mathrm{M}(0.05-0.28)$ & $0.3 \mu \mathrm{M}(0.24-0.38)$ & $0.27 \mu \mathrm{M}(0.22-0.33)$ & $>200$
\end{tabular}

${ }^{\mathrm{a}}$ Data are presented as $\mathrm{IC}_{50}$ values and $95 \%$ confidence intervals obtained by nonlinear regression for all cell lines from three independent experiments. Doxorubicin (DOX) was used as positive control. Only compounds with $\mathrm{IC}_{50}$ values lower than $25 \mu \mathrm{g} / \mathrm{mL}$ in at least one cell line were considered active

$\beta$-, $\gamma$ - and $\delta$-elemene were identified as main compounds in other oils of Piper occurring at Brazilian Amazon, such as $P$. aleyreanum and $P$. dilatatum $[7,15]$. Furthermore, the monoterpenes $\alpha$-pinene and $\beta$-pinene have predominated in the oil of $P$. anonifolium [21]. The high content of bicyclogermacrene and germacrene D has also been found in oils of $P$. arboreum occurring on diverse Brazilian region [22-24].

\section{Antioxidant activity}

The oil of $P$. aequale reduced DPPH radicals, and the absorbance of reaction mixture displayed a decreasing at $517 \mathrm{~nm}$. After $30 \mathrm{~min}$, the inhibition of DPPH radical was $25.9 \pm 2.6 \%$ corresponding to $280.9 \pm 22.2 \mathrm{mg}$ ET/ $\mathrm{mL}$. The antioxidant activity of essential oils rich in terpenoids, showing different protective effects on lipid oxidation, due their functional groups, have been reported [25]. The oil of $P$. aleyreanum with predomination of $\beta$ elemene $(16.3 \%)$ and $\delta$-elemene $(8.2 \%)$ displayed potent antioxidant activity $(412.2 \pm 9.5 \mathrm{mg} \mathrm{ET} / \mathrm{mL})$ [15]. The oil of Chimonanthus praecox, a traditional Chinese plant which contains elemene, showed a marked antioxidant effect on scavenging peroxide and hydroxyl radicals [26]. Also, $\alpha$-pinene and $\beta$-pinene presents in the oil of $P$. aequale as majority compounds, have exhibited around $50 \%$ of the antioxidant activity of ascorbic acid, in the $\mathrm{DPPH}$ assay, and an $\mathrm{EC}_{50}$ value equivalent to $\mathrm{BHT}$ in a $\beta$-carotene/linoleic acid system [27].

\section{Anticholinesterase activity}

The oil of $P$. aequale showed a weak anticholinesterase activity, with a detection limit (DL) of $100 \mathrm{ng}$, Ie, about a hundred times less active than the standard physostigmine standard ( $\mathrm{DL}=1.0 \mathrm{ng})$. Previous studies reported that monoterpenes are most efficient on inhibition of AchE activity, in comparison with sesquiterpenes [28] $\alpha$-Pinene showed anti-cholinesterase activity equivalent to galantamine $\left(\mathrm{IC}_{50}=87.2 \mu \mathrm{M}\right)$, used as positive control. However, its isomer $\beta$-pinene displayed a not significant activity [29]. Miyazawa and Yamafuji [29] explain that a small activity is due to the synergistic effect of the two compounds ( $\alpha$ - and $\beta$-pinene), as well as their structural diversity in the active site of anticholinesterase, making it difficult to predict the potential for the structure-activity relationship.

\section{Cytotoxic activity}

The oil of $P$. aequale was tested in vitro against three cancer cell lines (HCT-116, colon; ACP-03, gastric; SKMEL19, melanoma) with increasing concentrations $(0.4-25.0 \mu \mathrm{g} /$ $\mathrm{ml}$ ) and compared with doxorubicin, a known anticancer drug, used in medical clinics. Only oils with $\mathrm{IC}_{50}$ values lower $25 \mu \mathrm{g} / \mathrm{ml}$ were considered active, in at least one cell line (Table 2). The oil was more potent against cell line of intestinal type gastric cancer (ACP-03, $\mathrm{IC}_{50}=1.54 \mu \mathrm{g} / \mathrm{ml}$ ), when compared with the cell line of colon cancer (HCT$\left.116, \mathrm{IC}_{50}=8.69 \mu \mathrm{g} / \mathrm{ml}\right)$. The oil does not display effect against the cells of melanoma cancer (SKMEL19) when compared with the doxorubicin.

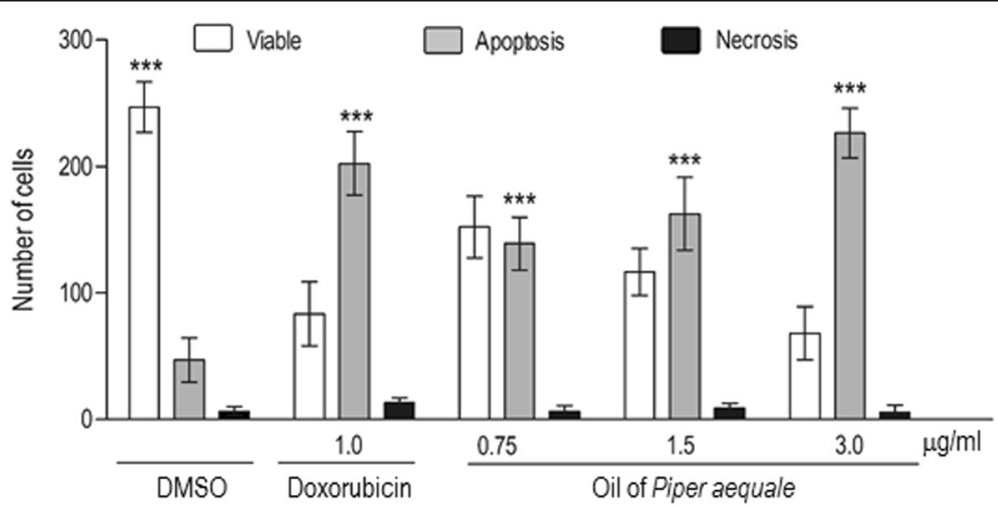

Fig. 1 Cell death pattern by differential staining with ethidium bromide/acridine orange, after $72 \mathrm{~h}$ of treatment with the oil of $P$. aequale. Doxorubicin was used as a positive control. Bars represent the mean \pm standard error of mean of three independent experiments. ${ }^{* *} P<0.001$ compared with the negative control by 2 way ANOVA, followed by Bonferroni test 
Also, the oil induces apoptosis in ACP-03 cell line, after $72 \mathrm{~h}$ of treatment, at all concentrations evaluated, when compared to negative control $(p<0.001)$. The oil at the concentration of $3.0 \mu \mathrm{g} / \mathrm{ml}$ did not display a significant difference in comparison to doxorubicin at $1.0 \mu \mathrm{g} / \mathrm{ml}$. See Fig. 1 .

In principle, the significant cytotoxic activity observed for the oil of $P$. aequalemay be attributed to high content of $\delta$-elemene $(19.0 \%), \beta$-pinene $(15.6 \%)$ and $\alpha$-pinene (12.6\%), probably, in association with the synergistic action involving other sesquiterpenes existing in the oil, as germacrene D, biciclogermacrene, $\beta$-atlantol and cubebol. Previously, the elemene-type sesquiterpenes were reported as proliferation inhibitors, stimulants of apoptosis and inductors of cell cycle arrest in the malignant cell [30-32]. Moreover, it has been found that $\beta$-elemene exerts anticancer activity of the brain, laryngeal, lung, breast, prostate, cervical, colon and ovarian $[30,33]$. $\delta$-elemene, an isomer with a different position at double bond existing in $\beta$-elemene, exerts antitumor activity by inducing apoptosis in cervical cancer cells, colorectal adenocarcinoma cells and human lung carcinoma mucoepidermoid cells [34-36].

\section{Conclusion}

Based on the results, it can be assumed that the oil of $P$. aequale inhibits the proliferation by inducing the apoptosis of the human gastric cancer cells. This activity is probably related to a most global effect of $\delta$-elemene, previously reported as a proliferation inhibitor, in association to other sesquiterpenes identified in the oil. Possible cytotoxic effect of oil was disregarded due to the absence of membrane damage. In this regard, the ability to induce lyses of mouse erythrocytes was unsuccessful.

\section{Acknowledgements}

We are grateful to Dr. Elsie Guimarães of Jardim Botânico do Rio de Janeiro (Rio de Janeiro state, Brazil) by botanical identification of $P$. aequale.

\section{Funding}

We are grateful to CNPQ/Bionorte, CAPES/Pró-Amazônia and FAPESPA/PA for their financial support.

\section{Availability of data and materials}

The dataset supporting the conclusions of this article is included within the article.

\section{Authors' contributions}

JKRS, RCM and JGSM participated in study designed; EHAA collected the plant material and determined the chemical profile using GC-MS. JKRS and LCP performed the extraction, antioxidant, anticholinesterase and cytotoxic experiments. RCM and RMRB contributed to the analysis of results of cytotoxic activity. Data were analyzed and the manuscript was written by JKRS, LCP and JGSM. All authors read and approved the final manuscript.

\section{Competing interests}

The authors declare that they have no competing interests.

Consent for publication

Not Applicable.
Ethics approval and consent to participate

Not Applicable.

\section{Author details}

${ }^{1}$ Programa de Pós-Graduação em Biotecnologia, Universidade Federal do Pará, 66075-900 Belém, PA, Brazil. ²Laboratório de Citogenética Humana, Universidade Federal do Pará, 66075-900 Belém, PA, Brazil. ${ }^{3}$ Programa de Pós-Graduação em Química, Universidade Federal do Pará, 66075-900 Belém, PA, Brazil. ${ }^{4}$ Programa de Pós-Graduação em Recursos Naturais da Amazônia, Universidade Federal do Oeste do Pará, 68035-110 Santarém, PA, Brazil.

Received: 8 April 2016 Accepted: 30 September 2016

Published online: 07 October 2016

\section{References}

1. Jaramillo MA, Manos PS. Phylogeny and patterns of floral diversity in the genus Piper (Piperaceae). Am J Bot. 2001;88:706-16.

2. Lago JHG, Chen A, Young MCM, Guimarães EF, Oliveira A, Kato MJ. Prenylated benzoic acid derivatives from Piper aduncum $L$. and $P$. hostmannianum C. DC. (Piperaceae). Phytochemistry. 2009;24:96-8.

3. Christophe W. Medicinal Plants of Asia and Pacific. Boca Raton: CRC Press; 2006.

4. Yuncker TG. The Piperaceae of Brazil. I. Piper - Group I, II, III, IV. Hoehnea. 1972:2:19-366.

5. Navickiene HMD, Alécio AC, Kato MJ, Bolzani VS, Young MCM, Cavalheiro AJ Furlan M. Antifungal amides from Piper hispidum and Piper tuberculatum. Phytochemistry. 2000;55:621-6.

6. Silva JKR, Andrade EHA, Kato MJ, Carreira LMM, Guimarães EF, Maia JGS. Antioxidant capacity and larvicidal and antifungal activities of essential oils and extracts from Piper krukoffii. Nat Prod Commun. 2011;6:1361-6.

7. Andrade EHA, Alves CN, Guimarães EF, Carreira LMM, Maia JGS. Variability in essential oil composition of Piper dilatatum L.C. Rich. Biochem Syst Ecol. 2011;39:669-75.

8. Maxwell A, Dabideena D, Reynolds WF, McLean S. Neolignans from Piper aequale. Phytochemistry. 1999;50:499-504.

9. Setzer WN, Park G, Agius BR, Stokes SL, Walker TM, Haber WA. Chemical compositions and biological activities of leaf essential oils of twelve species of Piper from Monteverde, Costa Rica". Nat Prod Commun. 2008;3:1367-74.

10. Bernard CB, Krishnamurthy HG, Chauret D, Durst T, Philogène BJR, SánchezVindas P, Hasbun C, Poveda L, San Román L, Arnason JT. Insecticidal defenses of Piperaceae from the Neotropics. J Chem Ecol. 1995;21:801-14.

11. Chiriboga P, Ximena Miño C, Moreta PL, Silva E. Actividad biológica en especies del género Piper. Rev Cubana Plant Med. 2005. Special Issue.

12. Van den Dool H, Kratz PDJA. Generalization of the retention index system including linear temperature programmed gas-liquid partition chromatography. J Chromatogr A. 1963;11:463-71.

13. Sarrazin SLF, da Silva LA, de Oliveira RB, Raposo JDA, da Silva JKR, Salimena FRG, Maia JGS, Mourão RHV. Antibacterial action against food-borne microorganisms and antioxidant activity of carvacrol-rich oil from Lippia origanoides Kunth. Lipids Health Dis. 2015;14:145. doi:10.1186/s12944-015-0146-7.

14. Marston A, Kissling J, Hostettmann K. A rapid TLC bioautographic method for the detection of acetylcholinesterase and butyrylcholinesterase inhibitors in plants. Phytochem Anal. 2002;13:51-4.

15. da Silva JKR, Pinto LC, R. Burbano MR, Montenegro RC, Guimarães EF, Andrade EHA, Maia JGS. Essential oils of Amazon Piper species and their cytotoxic, antifungal, antioxidant and anti-cholinesterase activities. Ind Crops Prod. 2014;58:55-60.

16. Mosmann T. Rapid colorimetric assay for cellular growth and survival: application to proliferation and cytotoxicity assays. I Immunol Methods. 1983;65:55-63.

17. Oliveira AC, Hillard EA, Pigeon P, Rocha DD, Rodrigues FAR, Montenegro RC, Costa-Lotufo LV, Goulart MOF, Jaouen G. Biological evaluation of twentyeight ferrocenyl tetrasubstitued olefins: cancer cell growth inhibition, ROS production and hemolytic activity. Eur J Med Chem. 2011;46:3778-87.

18. Cury-Boaventura MF, Pompeia C, Curi C. Comparative toxicity of oleic acid and linoleic acid on Jurkat cells. Clin Nutr. 2004;23:721-32.

19. NIST - National Institute of Standards and Technology. Mass Spectral Library (NIST/EPA/NIH). Gaithersburg: The NIST Mass Spectrometry Data Center; 2005.

20. Adams RP. Identification of essential oil Components by gas chromatography/ mass spectrometry. 4th ed. Carol Stream: Allured Publ. Corp; 2007. 
21. Andrade EHA, Ribeiro AF, Guimarães EF, Maia JGS. Essential oil composition of Piper anonifolium (Kunth) C. DC". J Essent Oil Bear Plants. 2005:8:289-94.

22. Cysne JB, Canuto KM, Pessoa ODL, Nunes EP, Silveira ER. Leaf essentials oil of four species from the State of Ceará - Northeast of Brazil. J Braz Chem Soc. 2005;16:1378-81.

23. Navickiene HMD, Morandim AA, Alécio AC, Regasini LO, Bergamo DCB, Telascrea M, Cavaleiro AJ, Lopes MN, Bolzani VS, Furlan M, Marques MOM, Young MCM, Kato MJ. Composition and antifungal activity of essential oils from Piper aduncum, Piper arboreum and Piper tuberculatum. Quim Nova. 2006;29:467-70.

24. Santana HT, Trindade FTT, Stabeli RG, Silva AAE, Militão JSLT, Facundo VA. Essential oils of leaves of Piper species display larvicidal activity against the dengue vector, Aedes aegypti (Diptera: Culicidae). Rev Bras PI Med. 2015;17:105-11.

25. Ruberto G, Baratta MT. Antioxidant activity of selected essential oil components in two lipid model systems. Food Chem. 2000;69:167-74.

26. Lv JS, Zhang LL, Chu XZ, Zhou JF. Chemical composition, antioxidant and antimicrobial activity of the extracts of the flowers of the Chinese plant Chimonanthus praecox. Nat Prod Res. 2012;14:1363-7.

27. Wang W, Wu N, Zu YG, Fu YJ. Antioxidative activity of Rosmarinus officinalis L. essential oil compared to its main components. Food Chem. 2008;108: 1019-22.

28. Kivrak I, Duru ME, Öztürk M, Mercan N, Harmandar M, Topçu G. Antioxidant, anticholinesterase and antimicrobial constituents from the essential oil and ethanol extract of Salvia potentillifolia. Food Chem. 2009;116:470-9.

29. Miyazawa M, Yamafuji C. Inhibition of Acetylcholinesterase activity by bicyclic monoterpenoids. J Agric Food Chem. 2005;53:1765-8.

30. Wang G, Li X, Huang F, Zhao J, Ding H. Antitumor effect of beta-elemene in non-small-cell lung cancer cells is mediated via induction of cell cycle arrest and apoptotic cell death. Cell Mol Life Sci. 2005;62:881-93.

31. Yao YQ, Ding $X$, Jia $Y C$, Huang $C X$, Wang $Y Z$, Xu YH. Anti-tumor effect of beta-elemene in glioblastoma cells depends on p38 MAPK activation. Cancer Lett. 2008;264:127-34.

32. Liu J, Zhang Y, Qu J, Xu L, Hou K, Zhang J, Qu X, Liu Y. ß-Elemene-induced autophagy human gastric cancer cells from undergoing apoptosis. BMC Cancer. 2011;11:183-93.

33. Li X, Wang G, Zhao J, Ding H, Cunningham C, Chen F, Flynn DC, Reed E, $\mathrm{Li} Q \mathrm{QQ}$. Antiproliferative effect of beta-elemene in chemoresistant ovariancarcinoma cells is mediated through arrest of the cell cycle at the G2-M phase. Cell Mol Life Sci. 2005;62:894-904.

34. Wang XS, Yang W, Tao SJ, Li K, Li M, Dong JH, Wang MW. Effect of delta-elemene on Hela cell lines by apoptosis induction. Yakugaku Zasshi. 2006;126:979-90.

35. Xie CY, Yang W, Li M, Ying J, Tao SJ, Li K, Dong JH, Wang XS. Cell apoptosis induced by $\delta$-Elemene in colorectal adenocarcinoma cells via a mitocondrial-mediated pathway. Yakugaku Zasshi. 2009:2009(129):1403-13.

36. Xie CY, Yang W, Ying J, Ni QC, Pan XD, Dong JH, Li K, Wang XS. B-Cell lymphoma-2 over-expression protects $\delta$-elemene-induced apoptosis in human lung carcinoma mucoepidermoid cells via a nuclear factor kappa B-related pathway. Biol Pharm Bull. 2011;34:1279-86.

\section{Submit your next manuscript to BioMed Central and we will help you at every step:}

- We accept pre-submission inquiries

- Our selector tool helps you to find the most relevant journal

- We provide round the clock customer support

- Convenient online submission

- Thorough peer review

- Inclusion in PubMed and all major indexing services

- Maximum visibility for your research

Submit your manuscript at www.biomedcentral.com/submit

) Biomed Central 